Copyright (C) 2019 by Academic Publishing House Researcher

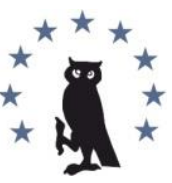

Published in the Russian Federation

European Researcher. Series A

Has been issued since 2010.

E-ISSN 2224-0136

2019, 10(3): 178-186

DOI: $10.13187 /$ er.2019.3.178

www.erjournal.ru

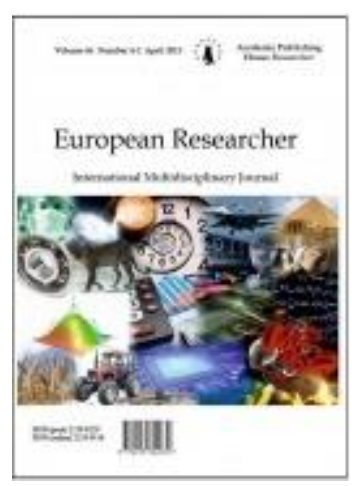

\title{
ODA Towards the Socio-Economic Development of Vietnam Today: Current Situation and Some Recommendations
}

\author{
Tung Nguyen Xuan ${ }^{a}{ }^{*}$ \\ ${ }^{a}$ Bac Ninh Province, Socialist Republic of Vietnam
}

\begin{abstract}
This research presents the reasoning issues of Official Development Assistance (ODA), especially it focuses on analyzing the role of ODA capital in the current social development of Vietnam, specifically: Firstly, ODA capital supplements fund for investing development; secondly, ODA helps to acquire scientific achievements, modern technology and development of human resources; thirdly, ODA assists to adjust economic structure and increase FDI. Along with that, the study assesses the current reality of the law on the management and use of ODA in order to find out the limitation, shortcomings, inconsistencies and problems arising in the implementation of the project, then it brings about the solutions to enhance the effective use of ODA, creating transparency of the Government's policies in attracting, managing and using these funds to the public in both national and international area.

Keywords: Economics Law, Law on Investment, Public Debt management, Official Development Assitance, Social Development, Concessional Loan, Vietnam, ODA capital, role of ODA capital.

\section{Introduction}

ODA stands for Official Development Assistance or Official Development Aid. The Law Dictionary explains that ODA is the official capital for development cooperation. This is a form of non-refundable or refundable aid (long loan term (from 2O-3O years) and may be extended from 10 to 20 years) or concessional credit (for low interest rates - depending on the borrowing objectives and borrowing countries) of the Government, agencies of the United Nations, government organizations, international financial institutions (IMF, WB, ADB), which collectively referred to as foreign partners of the Governments and people of the countries receiving aid.

Vietnam is undertaking industrialization and modernization according to the guidelines set out at the VIII National Congress of the Communist Party of Vietnam with the goal of increasing the income per capita to 1500 USD in 2020, which means it increases 7 times higher than the level in 1995. In the period of 2016-2020, besides the opportunities and advantages, Vietnam also has to face and overcome significant difficulties and challenges on the way of development. Especially, the requirements of development are very large, particularly the requirements for infrastructure development, social security guarantee, social welfare, people's lives improvement, requirement for the development of education and health care, national defence and security guarantee are growing faster while Vietnamese resources are rather limited. In addition, the limitation in state governance
\end{abstract}

\footnotetext{
${ }^{*}$ Corresponding author

E-mail addresses: mrtung310@gmail.com (T. Nguyen Xuan)
} 
to the economy, restrictions of economic structure, institutions, laws and policies have not yet met requirements for development and international integration. To accelerate the development process in order to achieve the objectives set out in the Socio-Economic Development Strategy for 10 years from 2011 to 2020 and overcome the middle income trap, Law on State Budget 2002, 2015 (Law on State Budget 2002, 2015), Law on Public Debt Management 2017 (Law on Public Debt Management, 2017), Decree 132/2018 / ND-CP amend and supplement a number of articles of Decree No. 16/2016/ND-CP on management and use of ODA and concessional credit of foreign donors (Decree N132/2018/ND-CP); Project towards attraction, management and use of ODA capital project for the attraction, management and use of ODA and concessional loans of foreign donors in the period 2011-2015, 2016-2020 (Decision approval...) has been issued.

In general, the projects that Vietnam chooses and mobilizes ODA loans mostly play an important role in developing the "backbone" industries of the country, with the scale and demand of large investment capital, high requirement for technique, technology. However, over the time of implementation, the weakness of the provisions of the Law on State Budget 2002 (Law on State Budget 2002), ODA managing and using project in 2011-2015 period had led to a series of negativities such as the violation at PMU 18 under the Ministry of Transport, Hai Phong port rehabilitation and upgrading project and many important projects belong to oil and gas industries, transportation,... (Trinh Thi Hang, 2019). It is time for the National Assembly to spend more time considering and strictly handling them. It is necessary to have clear and specific regulations and sanctions to deal with violations of organizations and individuals related to the management and use of ODA capital so that to avoid the corruption and wastefulness can affect the quality of constructions, which makes Vietnam to lose prestige towards ODA sponsors. These contents will be fully presented in the article.

\section{Document and study method}

2.1. This study was conducted on international treaties, current regulations of Vietnam law on the orientation of attracting, managing and using ODA and concessional loans of foreign sponsors and previous legal provisions. Simultaneously, this study was also executed basing on reference to published studies, such as: "The law on management and use of official development assistance (ODA) and concessional loans of foreign donors at the observation from current status of investment projects in the power industry (Do Thi Hong Hanh, 2016); Judge Shigeru Oda and the progressive development of international law: opinions (declarations, separate opinions, dissents) on the International Court of Justice, 1976-1992 / Edward McWhinney , ODA capital towards the support of development in policies, regime and administrative reform ( Vu Thi Thu Hang, 2015), Reform of managing system, use and inspection of ODA capital in new period (Nguyen Ba Hung, Pham Tien Chien, 2016), Factors that influence the effect of using ODA in road of Vietnam (Trinh Thi Hang, 2019)...

2.2. This research is completed by simultaneously using different research techniques such as analysis, general, dialectical materialism, interpretation, comparison, history,... to dissect and comment those stipulations, relating issues in which focus on analyze the role of ODA and concessional loan towards the social development of Vietnam.

\section{Discussion}

Vietnam has become a developing country with the medium income. In the face of challenges for integration which have been more deeply, the policy of capital aid from foreign donors to Vietnam has been drastically changed. strong and radical transformation from development aid relationship to partnership. Prior to the new requirements of cooperating development, the law stipulates the particular field to use ODA capital (Decree N132/2018/ND-CP, Art 5) as follows:

1. Socio-economic infrastructure, especially traffic infrastructure and social infrastructure (healthcare, education, vocational training), smart city development, irrigation.

2. Study and implementation of institutional and administrative reform.

3. Development of human resources, technology transfer and development.

4. Environmental remediation and improvement, natural disaster recovery and

preparedness, climate change adaptation and green growth.

5. Use as state investment in PPP projects

6. Other prioritized fields decided by the Prime Minister. 
Originating from the need of economic development, ODA was created to help poor countries to solve the shortage of capital. The concession of ODA is shown in the fact that ODA is only for developing and slow developing countries for development purposes. Specific conditions are as follows: firstly, the GDP per capita is low, secondly, the objectives of using ODA capital of these countries must be consistent with the policies and orientations, preferred in the relationship between the donor country and recipient of ODA. Vietnam has been receiving ODA since 1993. In the journey of nearly 30 years of renovation, ODA has helped to address the shortage of capital, contributed to the achievement of not only economic but also aspects of cultural-social life, education and health have also been significantly improved, the political situation is stable, national defense and security are strongly maintained, international cooperating relations are increasingly extensive. In order to achieve the above successes, besides the effective exploitation of domestic resources, the external assistance in which official development assistance (ODA) also plays the leading role, specifically:

\section{develop.}

Firstly, ODA is an important source of capital supplement for investment to

The industrialization and modernization process that Vietnam is implementing requires a huge amount of investment capital for a comprehensive renovation. However, due to the low starting point of Vietnam which is significantly less than others country in the region and around the world, only mobilizing domestic capital cannot meet its requirement. Therefore, ODA becomes an important source of external capital to meet the needs of capital for investment to develop.

Table 1. ODA signed towards industry and field in period 2011-2015 Unit: million dollars

\begin{tabular}{|c|c|c|c|c|}
\hline \multirow[b]{2}{*}{ Industry, field } & \multirow[b]{2}{*}{$\begin{array}{c}\text { Sum of ODA } \\
\text { and } \\
\text { concessional } \\
\text { credit }\end{array}$} & \multicolumn{2}{|c|}{ In which } & \multirow[b]{2}{*}{ Percentage \% } \\
\hline & & $\begin{array}{c}\text { ODA and } \\
\text { concessional } \\
\text { credit }\end{array}$ & Aid & \\
\hline 1. Transportation & $9,913 \cdot 73$ & $9,565.94$ & 347.79 & 35.68 \\
\hline $\begin{array}{l}\text { 2. Environment (supply water, } \\
\text { cope with climate change, ...) } \\
\text { and urban development }\end{array}$ & $5,181.26$ & $5,048.76$ & 132.51 & 18.65 \\
\hline 3. Energy and industry & $4,762.50$ & $4,730.15$ & 32.34 & 17.14 \\
\hline $\begin{array}{l}\text { 4. Agriculture and rural } \\
\text { development - Eliminate hunger } \\
\text { and reduce poverty }\end{array}$ & $2,632.23$ & $2,517.79$ & 117.44 & 9.47 \\
\hline 5. Health - Society & $1,292.30$ & $1,073.12$ & 219.18 & 4.65 \\
\hline 6. Education and Training & 930.13 & 767.85 & 162.28 & 3.35 \\
\hline $\begin{array}{l}\text { 7. Other industries: } \\
\text { technolontific } \\
\text { enhancement regime capacity }\end{array}$ & $3,070.14$ & $2,872.35$ & 242.79 & 11.05 \\
\hline Total & $27,782.29$ & $26,527 \cdot 35$ & $1,254.34$ & 100 \\
\hline
\end{tabular}

Source: Ministry of Planning and Investment

The infrastructure and technology of Vietnam is very old and it also endures the severe destruction of war, however, due to the timely disbursement of ODA capital, the infrastructure system has been relatively modern developed with a network of electricity and post and telecommunications covering all provinces and cities nationwide, many roads have been renovated and upgraded, many seaports and airports have been built and expanded, and especially the introduction of industrial parks, export processing zones and high-tech zones have created a very suitable environment for the operation of domestic and foreign enterprises. There are some projects with ODA capital are invested throughout Vietnam, such as: In the North, there are projects of Thanh Tri Bridge, Belt Road 3, Terminal T2 Noi Bai International Airport, Nhat Tan 
Bridge. ... and the network of national highways linking major cities in the North such as Hanoi and Hai Phong has been completed, contributing to improve the investment environment in Hanoi and the Northern region. In the South, many bridges on National road 1 and the North-South unified railway are built and upgraded with Hai Van road tunnels in the Central region, Can Tho bridge in the Mekong region, traffic connecting the two regions - the North and South of Vietnam have significantly improved, contributing to the socio-economic development of each region. In addition, three important international ports are Lach Huyen international port (Hai Phong), Cai Mep Thi Vai port (Ba Ria-Vung Tau), Da Nang port in the Central and Tan Son Nhat Airport station, which are Vietnam's gateway of airports and seaports have also been built. In addition to investing in the development of infrastructure systems, economic and technology, a large amount of ODA has been used to invest in the development of education and healthcare, supporting the development of agriculture...

\section{Secondly, ODA helps to absorb modern scientific, technological achievements and develop human resources.}

For Vietnam, the nature of industrialization and modernization is a fundamental and comprehensive transformation of production, business, economic and social management activities from the use of manual labor to use labor force along with industry, advanced and modern facilities based on scientific progress. Through ODA projects, donors have activities to help Vietnam improve science and technology and develop human resources such as: providing technical documents, organizing seminars with the participation of foreign experts, sending Vietnamese office workers to study abroad, organizing study tours to study and experience in developed countries, sending experts directly to Vietnam to support the project and provide technical equipment, modern technology lines for programs and projects. It is through these activities that donors have contributed significantly to the development of high quality human resources for Vietnam, creating more jobs, raising the level of science and technology, and this is the final sustainable, long-term benefits to Vietnam.

Thirdly, ODA helps to adjust economic structure, contribute to increasing the ability to attract FDI and create conditions to expand investing development.

The world economy recovers slowly and carries many risks that threaten sustainable development on a global scale. In addition, international integration takes place widely and strongly in the region and on a global scale within the framework of bilaterally and multilaterally Free Trade Agreements, has provided great development opportunities along with challenges for nations and peoples. Therefore, ODA projects that donors give to Vietnam mostly prioritize to develop economic and technical infrastructure. As in energy and industry, the total amount of ODA and concessional loans signed with Vietnam in the period of 2011-2015 reached about USD 4,762 million, equal to $17.14 \%$ of the total value of ODA and concessional loans signed in the same period. ODA and concessional loans have been used effectively, reflected in the strong development of electricity systems in power sources, grids transmission, grids distribution, reliable improvement, safety of operating system... (Decision No.251/QĐ-TTg, 2016). Besides, these aids are a source of foreign currency supplement, which to strengthen the international payment balance of developing countries... All of which contribute to the adjustment of economic structure in Vietnam. 


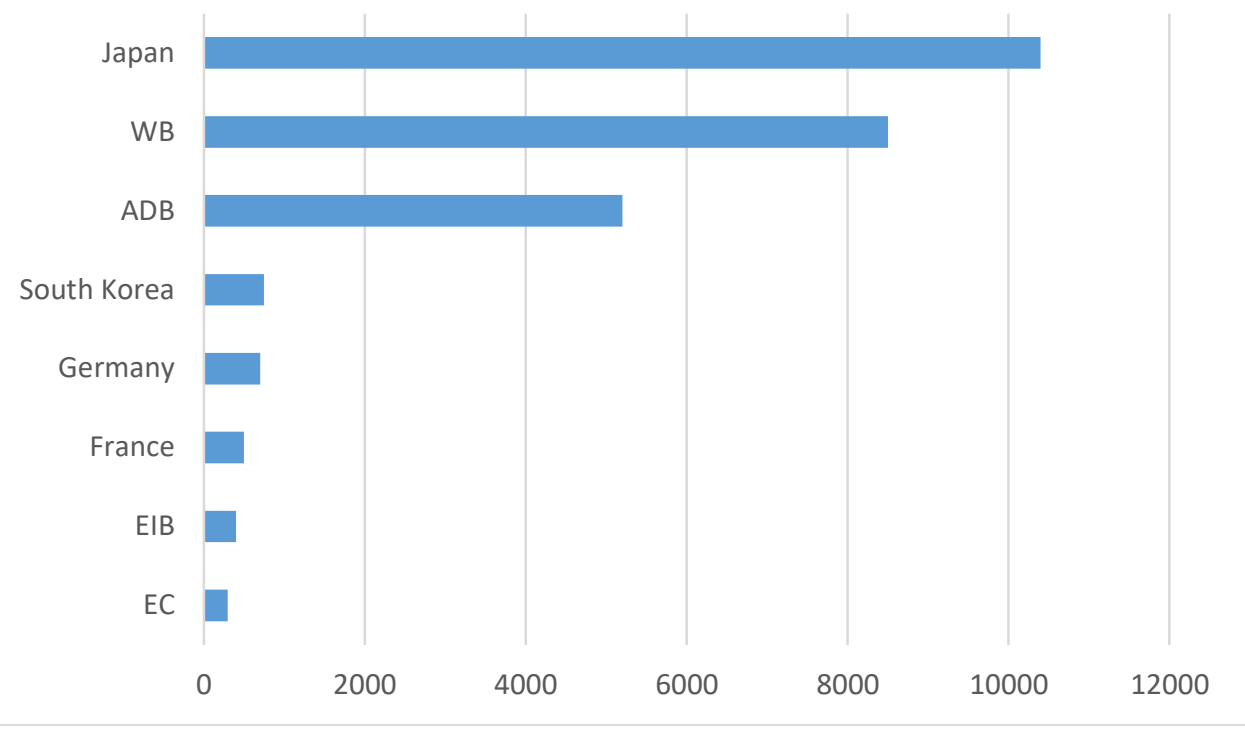

Fig. 1. ODA capital structure and concessional loan signed to sponsor period 2011-2015 Unit: million dollars

\section{Source: Ministry of Planning and Investment}

When foreign investors decide to invest in a country, they are primarily concerned with the profitability of invested capital in that country. Hence, a weak infrastructure such as an incomplete transportation system, inadequate and outdated means of communication, an inadequate energy supply system will discourage investors because the costs they have to incur for the use of facilities will grow up. As such, government investment in upgrading, improving and building new infrastructure, financial systems and banks is essential to make the investment environment become more attractive. Obviously, ODA is not only an important additional funding source for development, but also has the effect of raising the level of science and technology, adjusting economic structure and increasing the ability to attract capital from FDI.

In particular, FDI has created many new industries and products such as oil and gas exploitation, car production, motorbikes, electronics and telecommunications ... contributing to satisfying domestic demand and significantly increasing the development of Vietnamese industry. Through FDI, it has initially formed the system of Industrial Parks and Export Processing Zones. This is the right direction to contribute to a more rational industrial allocation, improve investment efficiency. With these new occupations, Vietnam creates many jobs, especially when the Vietnamese population is in the "golden population" period, helping to stabilize society and ensure national welfare.

In this time, ODA capital flows are mobilizing with many new nuances. Regarding to the global aid policy, countries which are members of OECD/DAC organization will apply ODA policies in the direction of binding the debt sustainability rules of the International Monetary Fund (IMF) and the lending policy of World Bank (WB). This is considered a positive move to protect lowincome countries from excessive lending. Future grants will focus on addressing global development challenges, focusing more on underdeveloped countries, combining harmoniously with other development funding sources, engaging strictly between poverty reduction and sustainable development to support the implementation of Agenda 2030 of the United Nations Agenda for Sustainable Development (SDGs). The change in the world situation is one of the factors affecting the attraction of ODA capital in Vietnam, thus Vietnam needs to grasp the mobilization trends of ODA capital to have effective measures to attract ODA from donors.

Therefore, it can be affirmed that, before the above challenges, Vietnamese State has made positive changes in orienting strategies and policies, creating synchronous solutions for institutional improvement, organizing improvement, strengthening the management capacity and implementation of ODA and concessional loans of foreign donors in order to effectively use the 
signed aid and simultaneously mobilize new aid to prepare for period after 2020. Vietnamese law in recent years has made positive changes to pave the way for ODA projects to be invested in Vietnam. As we can see, laws on governing social order and safety often have a longer "life expectancy" than economic laws, especially laws on investment. This is understandable because the world economy is always fluctuating, the law must be "superstructure", timely adjusting problems to better suit the domestic economic development and attracting international capital. The evidence for this is shown as follows: The decision on the scheme to attract ODA is always replaced to suit each period of 2011-2015 and 2016-2020 (Decision approval...), Decision No 216/QĐ-TTg date 13/2/2018 (Decision No.216/QD-TTg, 2018) adjusts Decision No 50/QĐ-TTg date 11/1/2018 (Decision No.50/QD-TTg, 2018) (early born before that) to be more clear in stipulating about the function, task and list of agencies that preside to write about management and use of ODA... This is the basis for industries and fields to mobilize and use ODA and concessional loans of foreign donors as foundation for donors to use in the policy-making process, building programs of cooperation development with Vietnam at regional, national, ministerial, sector and local levels. At the same time, it also aims to make the policies Government of Vietnam in attracting, managing and using these funds to be clearer to a wide range of national and international public.

Beside the positive achievements achieved when investing ODA capital into Vietnam, there are still some issues as follows:

\section{Firstly, the investment capital is not really effective and it still shows the dispersion and lacks offocus}

ODA can cause debt (ODA includes: non-refundable aid, mixed aid and refundable aid). In some countries, due to the inefficient use of ODA, it can create a temporary growth, but after a while, it may go in debt again due to the inability to repay. (Decree No 132/2018/ND-CP, Art1.10: ODA loan means a foreign loan with at least $35 \%$ grant element if the loan is tied to mandatory procurement of goods or services as required by the foreign sponsor, or at least $25 \%$ grant element if it is an untied aid). The issue here is that ODA capital has no capability to directly invest in production, especially the export (Decree No 132/2018/NĐ-CP, Art 6.5 ODA loans and concessional loans shall only be used for development investment instead of regular spending) while the payment of debt relies on the export then collects foreign currency.

Through the evaluation of ODA mobilization projects in Vietnam, it can be seen that the ODA resource hasn't got a basic and effective strategy; it still shows the dispersion and lacks of focus, proper attention in considering the effectiveness of loan using. These limitations and shortcomings are pointed out at all stages of the project. A 2018 report of State Audit sent to the National Assembly had shown that, among the 27/42 projects using ODA loans of the Ministry of Transport, the capital increased by more than VND 122.350 billion and nearly USD 97.3 million. Many negotiated projects and signed loan agreements with disadvantage binding terms, have led to the appointment of contractors for foreign investors, while some projects use high cost of international consultancies... (Anh Minh, 2019).

\section{Secondly, inadequacies in the management and use of ODA capital have lead to a "capital hike"}

Results from many localities show that many projects are small scale and are not synchronous, not yet associated with the overall plan. Another drawback is that the work of planning, allocating capital in many cases is not close to the actual needs. For example, in Quang Tri province, the disaster management project (WB5) plans to allocate 13.6 billion VND while disbursement is $\mathbf{1 1 3 . 0 9 6}$ billion VND (eightfold). The Project for Restoring and Sustainable Management of Protection Forest in Quang Tri Province (JICA) plans to allocate VND 57 billion while the disbursement is VND 116.278 billion (twofold) (Nguyên Thảo, 2018).

The reason for the "price hike" of ODA projects is that the initial survey process of our State is not thorough, leading to the construction process with many additional factors to be adjusted, making the capital source more and more increase, bringing about a long completion time, which affects the efficiency of the project.

ODA is expected to be an important resource in the country's socio-economic development; however, in fact, many projects have inadequate use of efficiency, capital hike and have a high price of materials. In the construction process, projects often rely too much on capital and contract 
providing partners, when the agreement is often detrimental to the Vietnamese side, such as: limiting the contractor, using technical equipment and experts of the country lent at a high cost ... Typically, Cat Linh - Ha Dong project, it had to adjust the total investment from VND 8,770 billion to VND 18,001.6 billion, an increase of VND 9,231.6 billion - equivalent to 205.27\%; Ben Thanh Suoi Tien project has a capital hike of over VND 30,00o billion (Luân Dũng, 2019).

\section{Thirdly is the responsibility of agency that manages ODA.}

According to the supervision of the Finance and Budget Committee of the National Assembly, in the period of 2011-2015, the allocation of ODA and foreign concessional loan plans is kinds of taking form, leading to the actual disbursement exceeds the estimate really large, which increase over-expenditure more than estimate approved by the National Assembly.

Regarding the responsibilities of State agencies in the management and use of ODA nowadays, many issues of great concern are being placed. First of all, it is the responsibility of the Ministry of Planning and Investment, the Ministry of Finance and concerned ministries and branches. Accordingly, the Law on State Budget 2015 has clearly defined the responsibilities of the Ministry of Planning and Investment as the focal point, taking the lead in mobilizing, coordinating, allocating management and use of ODA; The Ministry of Finance manages the State budget fund. However, in reality, the coordination between ministries is not effective, it is still lax in management and it seems that the regulations on coordination among agencies are just encouraging implementation. In addition, the management of ODA projects has not been homogeneous, and it is fragmented each agency manages a stage. Therefore, when a problem occurs, the main responsibility is not clearly defined on which agency, creating the blame on each other and irresponsibility among agencies. When it is unclear in the regulations on functions and responsibilities as well as sanctions for violations, corruption easily occurs. Typical case is the negative one at PMU 18 in 2007 with the involvement of many Government cadres. The construction companies cut back on supplies and changed structures (the piles were designed as iron poles but replaced by bamboo piles), officials in this corruption case had millions of dollars to gambling and dissipating...

Meanwhile, according to current regulations, the role of the receiving company has not been clarified; there is also a "vague" responsibility between the constructing company and the capital management agency (the State). In addition, the responsibilities of relevant agencies, organizations and individuals, especially the personal responsibility of the heads of organizational during the occurrence of violations are still difficult to be detected, and there has been no strong sanction enough to punish and collect back the ODA capital which had been loss or construction that uses inefficient capital sources.

Moreover, awareness of the significance of ODA resources of some officials is limited, partly due to the notion that funding is "free": the government borrows and allocates to localities and localities are not under pressure to pay debts and interest. Therefore, many projects are "drawn" to borrow money and they do not pay attention to practical efficiency, have not seen the responsibility to manage and use it economically and effectively. The ministries, branches and localities are not really drastic and proactive in the process of implementing, there is still the thought of "relying, expecting" on ODA and concessional loans allocated by the central budget.

As a result, at present, in order to reduce the corruption of recipient countries, international financial institutions, firstly the World Bank (WB), after the IDA-17 period in 2017, it will stop providing ODA loans with concessional terms (IDA) and replace them with less advantageous conditions (IBRD). Accordingly, the Asian Development Bank (ADB) may also stop providing loans with concessional conditions (ADF) to move to loans with less concessional conditions (OCR) in one or two years after the WB (Decision No.251/QĐ-TTg, 2016).

Facing the above limitations, a number of solutions are needed to enhance, attract and improve the efficient use of ODA in the up coming time, specifically as follows:

\section{Firstly, further improve on the legal framework, mechanisms and policies on foreign investment.}

Accordingly, it is necessary to improve the institutional framework on the management and use of ODA capital to ensure the consistency and synchronization between domestic legal documents and harmony with donors (such as Japan investing ODA in Vietnam. They only invested in Yen. Russia invested ODA through scholarships to study abroad ...), simplify processes and procedures. Especially, it is need to clearly define the functions and tasks of the agencies in 
charge of ODA management and use, with specific sanctions to handle with violating individuals and organizations, and need to specify the composition of the Criminal Law to strictly handle and have measures to recover the capital that was lost.

Besides, it is necessary to increase the responsibilities of the company that receives the loan. In the current regulation, it is necessary to increase the proportion of self-borrowing and selfpaying rather than the company receiving capital from the State and then the responsibility to pay returning to the State. Hence, the recipients of capital must be more responsible in designing the project, agreeing on terms to minimize the disadvantage for the capital user. Particularly for ODAfunded projects that are $100 \%$ financed by the State, it is given more autonomy to bring out accurate design and no deviation during deployment.

\section{Secondly, it is necessary to have solutions to effectively use ODA capital.}

In short term, policy makers need to integrate ODA-funded projects into specific investment plans, sectoral and local development plans, coordinating with other projects with others sources of funding to be implemented in a synchronized and effective way. Along with that, it is necessary to set up a unified inspection agency for the effectiveness of ODA use throughout the country, each ministry and branch participating in any stage of the ODA project also needs set up an inspection committee to check the progress of the project at any stage and cross-check other agencies in carry out the activities.

Accelerating the reform of administrative procedures, publicizing all stages of the investment process on the official website of agency in responsible for implementing project, aiming to further promote transparency through e-government.

Furthermore, it is also necessary to organize seminars and conferences to consult national and international experts, as well as introduce the need to use ODA capital on the mass media, committing to comply with the requirements of investors (environmental protection, climate change prevention, gender equality guarantee, anti-poverty, disease ...) to call for the support and assistance of bilateral and multilateral sponsors in the world.

\section{Results}

From the above analyzed contents, this research has analyzed and clarified the role of ODA capital for national development. In addition, the study also pointed out the limitations, shortcomings and bottlenecks in the content and practice of implementing the current legal provisions on ODA management. On that basis, find the causes, propose recommendations to further improve these legal provisions on capital management and social solutions to effectively use this capital source.

\section{Conclusion}

In the field of development and cooperation, Vietnam continues to receive agreement and the positive support from the international community, however, along with that, the development and cooperation with donors will continue to have significant changes, completes the transition period from development aid relationship to partnership. Through the overall assessment, it can be affirmed that Vietnam's legal system is being more and more adjusted to conform to international practices, administrative procedures are continuously reformed to create advantageous conditions for the flow of foreign capital investing in our country. However, in recent years, there have been many corruption cases from foreign investment capital sources, which have caused the loss of confidence from investment partners. Therefore, donors continue to adjust development, cooperation policies with Vietnam in the direction of gradually shifting from ODA provision to loans with less preferential terms, focusing strongly on trade, co-operate in investment or terminate development assistance programs for Vietnam. This fact has set a requirement for the coming time to use ODA capital most effectively, and to select investment objectives and preferential areas to invest, and then have safe policies and solutions on foreign debt.

\section{References}

Anh Minh, 2019 - Anh Minh (2019). Auditors find out thousands of billion difference in ODA projects, published on VNexpress Newspaper date 21/5/2019. [Electronic resource]. URL: https://vnexpress.net/kinh-doanh/kiem-toan-phat-hien-hang-nghin-ty-chenh-tai-cac-du-an-vonoda-3926553.html?ctr=related_news_click 
Decision No 251/QĐ-TT - Decision No 251/QĐ-TTG date 17/2/2016 of Prime Minister about ratifying the project "Orientation on attracting, managing and using ODA and concessional loan from foreign sponsors in period 2016 - 2020".

Decree No 132/2018/NĐ-CP - Decree No 132/2018/NĐ-CP about adjust, supplement some articles of Decree No 16/2016/NĐ-CP date 16/3/2016 in managing and using ODA and concessional loan from foreign sponsors which have stipulation of preferential fields to use ODA and concessional loan.

McWhinney, 1992 - McWhinney Edward (1992). Judge Shigeru ODA and the progressive development of international law : opinions (declarations, separate opinions, dissents) on the International Court of Justice, 1976-1992.

Judicial Academy, 2006 - Judicial Academy (2006). Legal dictionary, Judiciary Publisher, Hanoi, 2006.

Law on Investment 2014 - Law on Investment 2014.

Law on Public Debt 2017 - Law on Public Debt 2017.

Law on State Budget 2015 - Law on State Budget 2015.

Lê Chi Mai, 2016 - Lê Chi Mai (2016). How should Vietnam prepare when there is no ODA, Political reasoning no 6/2016.

Luân Dũng, 2019 - Luân Dũng (2019). The railway project Cát Linh - Hà Đông "capital hike" over $200 \%$, published on Soha newspaper date 06/07/2019. [Electronic resource]. URL: https://soha.vn/du-an-duong-sat-cat-linh-ha-dong-doi-von-hon-200-20190706082039343.htm

Nguyễn Bá Hùng, Phạm Tiến Chiến, 2016 - Nguyễn Bá Hùng, Phạm Tiến Chiến (2016). Renewing institutions of management, using and monitoring ODA capital in the new period. State Management Journal, No 1.

Nguyên Thảo, 2018 - Nguyên Thảo (2018). Management and use of ODA still show the dispersion and lacks ò focus. People Magazine. [Electronic resource]. URL: https://nhandan.org.vn/ baothoinay/baothoinay-kinhte/item/37322902-quan-ly-su-dung-vonoda-dan-trai-thieu-tap-trung.html

Phạm Thị Hồng Diệp, Bình Đình Viên, 2015 - Phạm Thị Hồng Diệp, Bình Đình Viên (2015). Effect of using ODA and less concessional loan in Vietnam. Management report of the State no $9 / 2015$.

Đỗ Thị Hồng Hạnh, 2016 - Đỗ Thị Hồng Hạnh (2016). Thesis of Master in Law. Law on management and use of official development assistance (ODA) capital and concessional loans of foreign donors from the observation point of current situation in electricity investment projects, Hanoi, 2016.

Trịnh Thị Hằng, 2019 - Trịnh Thị Hằng (2019). Factors affecting the efficiency of ODA use in road in Vietnam. Financial Magazine, 9. [Electronic resource]. URL: http://tapchitaichinh.vn/nghien-cuu-trao-doi/cac-nhan-to-tac-dong-den-hieu-qua-su-dung-odatrong-giao-thong-duong-bo-o-viet-nam-311995.html

Vũ Thị Thu Hằng, 2015 - Vũ Thị Thu Hằng (2015). ODA funding towards to the support for policy, institutional and administrative reform. State Management Journal, No 9.

Vương Thanh Hà, 2009 - Vương Thanh Hà (2009). Experience of some countries in managing ODA. BState Management Newspaper, No 9.

Website of Minister of Education and Training - Website of Minister of Education and Training. [Electronic resource]. URL: http://icd.edu.vn/250/thong-bao-tuyen-sinh-di-hoc-theodien-hiep-dinh-tai-lien-bang-nga-nam-2019.html/BPF/vi-VN/CMS_Cat/thong-tin-tuyensinh/CMS_Detail/1097 